\title{
THE IMPACT OF GUESTS' ATTITUDE AND SUBJECTIVE NORM ON WILLINGNESS TO PAY A PREMIUM FOR RENEWABLE ENERGY PRACTICES IN SRI LANKAN HOTEL INDUSTRY: AN APPLICATION OF THEORY OF REASONED ACTION (TRA)
}

\author{
Chalani, Kuruppu ${ }^{1}$ and Nadeesha, Ketakumbura ${ }^{2}$ \\ SLIIT, Faculty of Business, Malabe, Sri Lanka, chalani.k@sliit.lk \\ Sri Lankan Aviation College, Technical Training, Katunayaka, Sri Lanka, nadeeshaketakumbura@gmail.com
}

\begin{abstract}
This paper examines the guests' willingness to pay a premium for renewable energy practices in Sri Lankan hotel industry in a context where the renewable energy considered as an alternative source of energy that has a growing consumer demand. The aim of this research is to investigate the impact of guests' attitude and subjective norm on their willingness to pay a premium for hotels' 'renewable energy practices' by using the Theory of Reasoned Action. A structured questionnaire served as the main instrument in gathering primary data from 60 respondents. This study found that guests' attitude and social norms have a positive relationship with their willingness to pay a premium and both independent variables lead to a strong impact on dependent variable suggesting that, the guests with positive attitude and stronger social norms are more likely to pay a premium for renewable energy practices.
\end{abstract}

KEY WORDS: Hotel Industry, Renewable Energy, Guests’ Attitude, Subjective Norm, Theory of Reasoned Action (TRA)

\section{INTRODUCTION}

\subsection{Background of the Study}

The concept of sustainability originated with biologists and ecologists who used it to describe the rates at which renewable resources could be extracted or damaged by pollution without threatening the underlying integrity of ecosystems (Kamieniecki et al, 1997). In such context, implementation of renewable energy projects is one of the major goals in most of the countries of the world to achieve sustainable development. Renewable resource technology can be defined as the electricity produced from other than a conventional power sources such as biomass, wood, wood waste, municipal solid waste, landfill gas, biogas, ethanol, biodiesel, hydropower, geothermal, wind and solar (Bang, et al.,2000).

When looking at the Sri Lankan context, with the transition from agrarian structure to service oriented structure and with the increasing economic growth have led to create an increasing demand for energy within the country especially in travel and tourism sector. According to the World Travel and Tourism Council, the direct contribution of travel \& tourism to Gross Domestic Product (GDP) of the nation in 2017 was LKR687.4bn (5.3\% of GDP) and the sector has generated 404,000 jobs directly in 2017 representing $5.1 \%$ of total employment (World Travel \& Tourism Council, 2018). The hotel sector in Sri Lanka which is coming under the tourist accommodation sector, consists of 20 hotel chains which have been scattered throughout the country and Sri Lanka Tourism Development Authority (SLTDA) classifies the tourist accommodation sector into four different categories: including boutique villas and hotels, guesthouses, home stay units and tourist hotels.

The growing customer awareness about the global warming and concerns about the global energy crisis have become a drive to implement better environmental practices in hotel industry (IFC - World Bank Group, 2013). Further, it has been identified that the consumers who are looking for environmental products are willing to pay an additional amount for the environmental benefits (Kostakis and Sardianou, 2011).

Moreover, the previous studies have identified that customers would give more priority for choosing hotels that have ecofriendly approach over some standard hotels (Manaktola and Jauhari, 2007). Hence, the guests who are willing to pay more for a staying in a green hotel are the potential niche market for developing sustainable tourism in Sri Lanka and this research investigates how the gusts' attitude and subjective norm (social pressure) impact on their willing to pay a premium for the hotels that are using renewable energy sources with the application of Theory of Reasoned Action (TRA).

\subsection{Problem Statement}

According to the recent statistics, the tourist arrivals in Sri Lanka have been increasing over the last three decades and the Sri Lankan government has also set targets to increase the number of tourist arrivals. This in turn will result in increasing the resource utilization in hotel industry. As per the Statistical Digest 2017 - Ceylon Electricity Board (CEB), the Sri Lankan hotel industry accounted for $2 \%$ of total electricity sales in 2017 and there had been a growth of $10 \%$ over 2016's electricity sales. Moreover, according to the Sri Lanka National Water Supply and Drainage Board Annual Report - 2015, Sri Lankan tourist hotels accounted for $0.6 \%$ water consumption, equivalent to $2,667,000$ cubic meters. The fuel consumption of the Sri Lankan hotels also encountered a high percentage including diesel and furnace oil and there was a $49 \%$ of the energy usage in 2010 (IFC - World Bank Group, 2013). These facts depict that there is a high energy consumption in hotel sector resulting a massive damage to the environment. Hence, to minimize the huge cost incurred on imported fossil fuels and to minimize the emission of greenhouse gases (GHG), Sri Lankan hotel sector steering to use renewable energy resources of the country.

Using renewable energy practices can be considered as a great marketing initiative with the growing consumer base for green hotels. Therefore, it is important to attract and retain the 
customers who are looking for environmental benefits irrespective of the price. According to previous studies, Farhar (1996) indicated that $56-80 \%$ of respondents would pay a premium for environmental protection. On the other hand, Gleason et al. (1996) suggest that less than 5\% pay a premium for renewable power (Bang et al., 2000) Thus, this creates an opportunity for the researches to addresses the question whether guests are willing to pay a premium for renewable energy resources utilize in hotels and how the guests' attitude and social pressure impact on their decision?

\subsection{Significance of the Study}

Using of renewable energy has many advantages as it leads to reduce the greenhouse gas emission and result in creating many job opportunities in the tourism sector as this energy creation tends to be labour intensive than fossil fuel creation. As a country close by to the equator, availability of solar energy most of the year and being an island where the sea wind is available around the country is a positive point to emphasis the validity of this research on Sri Lanka. Therefore, the use of renewable energy reduces the dependence of foreign oil and many hoteliers in Sri Lanka are willing to adopt the renewable energy to maintain the sustainability and to obtain the competitive advantage in terms of cost and value addition. Hence, this initiative will create a win-win situation, in which both the hotel industry and environment benefit. Furthermore, by investigating the guests' attitude and subjective norm towards their intention to pay a premium for renewable energy, the hoteliers can implement marketing strategies to change the attitude of the guests in a way that there will be a positive impact on hotel profits. Accordingly, the hotels can charge a premium where they can obtain high returns for the investments. Moreover, being more environmental conscious in hotel practices will lead to obtain a greater recognition from different stakeholders which creates a favourable subjective norm and the hotel will be able to attract more guests who are looking for environmental performances.

\subsection{Objectives of the Study}

- To investigate the impact of hotel guests' attitude on willingness to pay a premium for renewable energy practices in hotels.

- To investigate the impact of subjective norms on willingness to pay a premium for renewable energy practices in hotels.

\section{LITERATURE REVIEW}

The public acceptance for green investments has been researched in global context and there is a high public concern for using renewable energy sources as it supports for sustainability development in many countries. Especially, Denmark and Germany have been recognized as the global leaders in renewable energy and also, South Korea and USA have implemented policies to promote the renewable energy sources (Ntanos et al., 2018). According to Ribeiro et al. (2014), in Portugal, there is a positive social attitude towards innovative renewable energy source investments and there is a high social concern for solar projects and new hydropower units. It has been observed that in Sri-Lankan context, there is a high emission of greenhouse gases (GHG) with the economic development in the country. Thus, Sri Lankan government policies have set a target to use $20 \%$ renewable energy by 2020 (Pushpakumara et al., 2014).
When considering about the tourism in Sri Lanka, some hotels already have adopted the green practices to meet the environmental responsibilities. The green practices can be divided in to four main categories including, energy efficiency (as energy using reduction with the same service level), water conservation, recycling, and clean air where renewable energy falls under the first category (Hieu and Rasovska, 2017). When analysing customer perspective, many customers have given priority for environmental aspects when consuming hospitality products. The empirical results suggest that $55 \%$ pay attention to environmental initiatives depicting a favourable attitude towards the green practices adopted by the hotel industry. Similarly, this study has identified that a firm which is environmentally friendly would obtain a competitive advantage over the other firms (Manaktola and Jauhari, 2007).

Moreover, some findings suggest that middle-aged people are more willing to pay for their stay in a hotel that use renewable energy. When considering the gender, men are more likely than women to pay extra amount for the accommodation in green hotels. Further, environmentally conscious tourists and adequately informed tourists are willing to pay more for renewable energy than usual guests. Nevertheless, the marital status and educational level are not statistically significant factors in determining the willingness to pay more for renewable energy (Kostakis and Sardianou, 2011).

\subsection{Theoretical Framework}

The 'Theory of Reasoned Action' has been widely used to study the consumer attitude towards renewable energy and it has been revealed that people who cared about environmental issues like pollution are willing to spend more for renewable energy (Bang et al., 2000). The TRA model (Fishbein and Ajzen, 1975) suggests that, people consider the consequences of alternative behaviours before engaging in them, and that they choose to perform behaviours that associate with desirable outcomes. According to this theory, the behavioural intention (BI) is derived from two factors including attitude toward the behaviour, and the subjective norms or perceived social pressure associated with the behaviour. Consequently, behaviours are determined by a person's intention to perform the behaviour (Gleason, 1996).

The 'attitude toward the behaviour' can be defined as the individual's positive or negative feelings about performing a behaviour and it is derived from two factors that is one's belief regarding the consequences arising from a behaviour which based on knowledge and concerns. The theory explains that there is a direct correlation between attitudes and outcomes. If a person believes that a certain behaviour will lead to a desirable outcome, then he/she is more likely to have a positive attitude towards the behaviour. On the other hand, if a person believes that a certain behaviour will lead to an undesirable outcome, then that person is more likely to have a negative attitude towards the behaviour (Fishbein and Aizen, 1975; Ajzen and Albarracín, 2007).

The 'Subjective norms' can be defined as an individual's estimate of the social pressures on him or her to perform or not to perform the behaviour (Ajzen et al., 1991) as people are affected by groups to which they belong and reference groups which they refer to opinion or judgment (Wang and Ritchie, 2010; Wang and Ritchie, 2012). Thus, subjective norms include two key elements which function together including individual's beliefs about how other people would like him or her to behave (normative beliefs) and to comply with the significant referents' 
opinions about the behaviour (motivation to comply) (Ajzen et al., 1991; Ajzen et al., 1980).

'Behavioural intention' is a function of both attitudes and subjective norms toward the respective behaviour. The past studies have identified that, stronger the attitude and the more positive the subjective norm, the stronger should be the person's intention to perform the behaviour (Miller and Katherine, 2005).

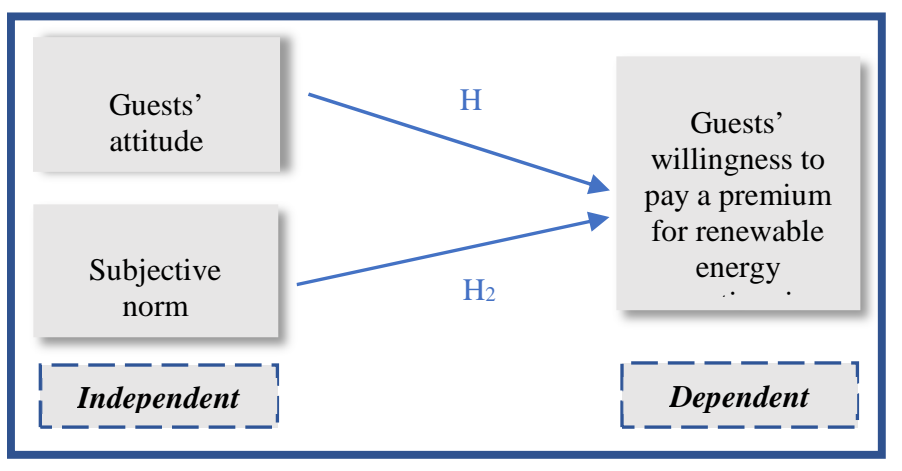

Figure 4. Conceptual Framework.

According to the Figure 1 the key independent variables tested in this study are 'guests' attitude' and 'subjective norm'. The 'guests' attitude' has been measured in terms of their knowledge about renewable energy, concern about the environment, pollution and water usage and belief about renewable energy. Thus, 09 items have been developed by referring to literature in order to operationalize the variable of 'guest attitude'. The 'subjective norm' has been measured by referring to the pressure exerting by the general public, government and NGO's to perform the intended behaviour and 03 items were developed to measure the 'subjective norm'. The dependent variable for this study is the 'willingness of the hotel guests' to pay a premium for renewable energy practices in hotels' or in other words the 'behavioural intention (BI) of guests to make a premium payment for renewable energy practices in hotels. Hence, 03 items were developed in terms of guests' acceptance level regarding the premium payment and the priority given for spending extra monies for renewable energy. Accordingly, the theory explains that the guest's attitude and subjective norms have a significant impact on their willingness to pay a premium for renewable energy practices in hotels.

Thus, the hypothesis can be developed as follows,

$\mathrm{H}_{1}$ : Guests' attitude has a significant impact on willingness to pay a premium for renewable energy practices in hotels.

$\mathrm{H}_{2}$ : Subjective norm has a significant impact on willingness to pay a premium for renewable energy practices in hotels.

\section{METHODOLOGY}

The research was conducted with a deductive approach by reviewing the relevant theories applicable for the area of interest. Hence, the Theory of Reasoned Action was tested accordingly. The data gathering was commenced mainly by referring to primary data. A quantitative approach was employed in this study and the research strategy adopted was 'survey' while a structured questionnaire served as the main instrument. The questionnaire was designed in a manner to capture how attitude and subjective norm impact on guests' intention toward paying a premium for renewable energy according to TRA model. Thus, the questionnaire consisted of 05 main sections which covered the demographic profile of the guests as well as the constructs relating to guests' attitude, subjective norm and behavioural intention to pay a premium for renewable energy. The reliability and the validity for the constructs were tested accordingly and the five-point likert scale was used to sum the values of each of the chosen option and to generate a score for each individual respondent. The secondary data was gathered through the past researches, other related publications and newspaper articles on similar topics and areas.

The study population consisted of guests who are employed under 09 job categories according to the 'International Standard Classification of Occupation' (ISCO) and the sample was selected through the purposive sampling method where the priority was given for the guests who are professionals as they have represented the largest group under the occupational classification of tourists in 2017 (SLTDA-Annual Statistical Report, 2017). Therefore, the sample for this study consisted of 60 'professionals' who have visited to a tourist hotel as a guest. This study was cross-sectional in nature since it was conducted in the last quarter of the year 2018, and the respective findings were discussed based on the data collected at that point of time. SPSS version 22 was used for the data analysis in arriving at the results and the interpretations.

\section{ANALYSIS AND DISCUSSION}

\subsection{Descriptive Analysis}

The below Table 1 displays the profile of the guests within the sample. In terms of gender, the majority of the study participants were female $(55 \%)$ and the age of the most participants ranged from 20 to 29 representing $85 \%$ of the total sample. Most of the professionals represented the other categories while $48.3 \%$ were falling under the range of Rs.20, 000 - Rs.49, 000 of monthly household income. Furthermore, majority of the guests possessed a bachelor's degree. When considering the guest's expected price range for the hotel service (per person), most of the guests have given priority for the price range of Rs. 2, 000 Rs. 5, 000. Moreover, according to the findings, $85 \%$ of the guests have visited as leisure travellers and majority (33.3\%) have visited to 3-star hotels comparing to the other categories. Moreover, when analysing the gust preference over the form of renewable energy, it was resulted that $33.3 \%$ of the guests like to see that the hotel uses renewable energy in water purification and $23.3 \%$ of the guests preferred to use renewable energy in architectural design (natural light) and $18.3 \%$ would like to use renewable energy in heating/cooling apparatuses.

Table 1. Descriptive Summary of Represented Tourist Guests.

\begin{tabular}{|c|c|c|}
\hline Gender & $\begin{array}{c}\text { Frequency } \\
(\mathrm{N})\end{array}$ & $\begin{array}{c}\text { Percentage } \\
(\%)\end{array}$ \\
\hline Male & 27 & $45 \%$ \\
\hline Female & 33 & $55 \%$ \\
\hline Age & & \\
\hline Below 20 & 2 & $3.3 \%$ \\
\hline 20-29 Years & 51 & $85 \%$ \\
\hline 30-39 Years & 7 & $11.7 \%$ \\
\hline Profession & 10 & $16.7 \%$ \\
\hline $\begin{array}{c}\text { Physical, Mathematical and } \\
\text { Engineering Science }\end{array}$ & 2 & $3.3 \%$ \\
\hline Life Science and Health & 10 & $16.7 \%$ \\
\hline Teaching & 38 & $63.3 \%$ \\
\hline Other & & \\
\hline Household Income/Month & 1 & $1.7 \%$ \\
\hline Below Rs. 20,000 & 29 & $48.3 \%$ \\
\hline Rs. 20,000- Rs. 49,000 & 15 & $25 \%$ \\
\hline Rs. 50,000- Rs. 79,999 & 15 & $25 \%$ \\
\hline Rs. 80,000 & &
\end{tabular}




\begin{tabular}{|c|c|c|}
\hline & $\begin{array}{l}\text { Frequency } \\
(\mathrm{N})\end{array}$ & $\begin{array}{c}\text { Percentage } \\
(\%)\end{array}$ \\
\hline \multicolumn{3}{|l|}{ Education } \\
\hline $\mathrm{A} / \mathrm{L}$ & 9 & $15 \%$ \\
\hline Bachelor's degree & 39 & $65 \%$ \\
\hline Masters or higher & 12 & $20 \%$ \\
\hline \multicolumn{3}{|l|}{$\begin{array}{l}\text { Price Range for the Hotel } \\
\text { Service /Person }\end{array}$} \\
\hline Below Rs.2,000 & 2 & $3.3 \%$ \\
\hline Rs.2, 000-Rs.5, 000 & 19 & $31.7 \%$ \\
\hline Rs.5, 000- Rs. 10,000 & 17 & $28.3 \%$ \\
\hline Rs. 10,000 -Rs. 15,000 & 15 & $25 \%$ \\
\hline Above 15,000 & 7 & $11.7 \%$ \\
\hline \multicolumn{3}{|l|}{ Purpose of Visit } \\
\hline As a Business Traveller & 0 & $0 \%$ \\
\hline As a Leisure Traveller & 51 & $85 \%$ \\
\hline Both & 9 & $15 \%$ \\
\hline \multicolumn{3}{|l|}{$\begin{array}{l}\text { Frequently Visited Hotel } \\
\text { Category }\end{array}$} \\
\hline 1-Star & 3 & $5 \%$ \\
\hline 2-Star & 3 & $5 \%$ \\
\hline 3-Star & 20 & $33.3 \%$ \\
\hline 4-Star & 18 & $30 \%$ \\
\hline 5-Star & 16 & $26.7 \%$ \\
\hline \multicolumn{3}{|l|}{$\begin{array}{l}\text { Preferred Form/Area of } \\
\text { Renewable Energy }\end{array}$} \\
\hline Architectural (Natural Light) & 14 & $23.3 \%$ \\
\hline Water Purification & 20 & $33.3 \%$ \\
\hline Heating/Cooling & 11 & $18.3 \%$ \\
\hline Air Ventilation & 6 & $10.0 \%$ \\
\hline Sanitation & 6 & $10.0 \%$ \\
\hline Food & 3 & $5 \%$ \\
\hline
\end{tabular}

\subsection{Pearson Correlation Coefficient}

The Pearson correlation has been adopted in this study to identify whether there is a significant relationship between the variables as explained in the Conceptual Framework.

Table 2. Correlations.

\begin{tabular}{|cc|c|c|c|}
\hline & & Attitude & $\begin{array}{c}\text { Subjective } \\
\text { Norm }\end{array}$ & $\begin{array}{c}\text { Behavi } \\
\text { oural } \\
\text { Intenti } \\
\text { on }\end{array}$ \\
\hline & $\begin{array}{c}\text { Pearson } \\
\text { Correlation }\end{array}$ & 1 & $.530 * *$ & $.540 * *$ \\
Attitude & Sig. (2-tailed) & & .000 & .000 \\
& $\mathrm{~N}$ & 60 & 60 & 60 \\
Subjective & Correlation \\
Norm & Sig. (2-tailed) & $.530 * *$ & 1 & $.629 * *$ \\
& N & 60 & 60 & 60 \\
& Pearson & $.540 * *$ & $.629 * *$ & 1 \\
Behavioural & Correlation & & & \\
Intention & Sig. (2-tailed) & .000 & .000 & \\
& $\mathrm{~N}$ & 60 & 60 & 60 \\
\hline
\end{tabular}

**. Correlation is significant at the 0.01 level (2-tailed).

According to the above Table 2, there is a moderate positive correlation of 0.540 between the independent variable of attitude and the dependent variable of behavioural intention under the significant level of 0.01 . This depicts that when there is a favourable attitude among the guests in terms of adequate knowledge about the renewable energy, concerned about the environment and belief about the renewable energy, the gusts are willing to pay more for renewable energy. Furthermore, there is a moderate positive correlation of 0.629 between subjective norm and behavioural intention under the significant level of 0.01 . This demonstrates that one's subjective norms such as pressure from general public, government and NGOs towards using renewable energy positively relates with their intention of paying more for renewable energy and the relationship is much stronger than the guests' attitude. Also, the results suggest that there is a positive moderate relationship between the two independent variables that is guests' attitude and the subjective norm under the significant level of 0.01 .

\subsection{Regression Analysis}

The regression analysis has been adopted in this study to model the relationship between the outcome variable (behavioural intention) and the predictor variables (attitude and subjective norm). In other words, this demonstrates how the variance in predictor variables explain the level of change in the outcome variable.

Table 3. Model Summary.

\begin{tabular}{|c|c|c|c|c|}
\hline Model & $\mathrm{R}$ & $\mathrm{R}$ Square & $\begin{array}{c}\text { Adjusted R } \\
\text { Square }\end{array}$ & $\begin{array}{c}\text { Std. Error of } \\
\text { the Estimate }\end{array}$ \\
\hline 1 & $.675^{\mathrm{a}}$ & .455 & .436 & .67426 \\
\hline
\end{tabular}

a. Predictors: (Constant), Subjective Norm, Attitude

b. Dependent Variable: Behavioral Intention

According to the Table 3, R Square $=0.455$ (Adjusted R Square $=0.436)$ and that describes $45.5 \%$ of the variance in the behavioural intention (willingness to pay a premium) is explained by the two predictor variables of guests' attitude and subjective norm.

Table 4. ANOVA

\begin{tabular}{|cc|c|c|c|c|c|}
\hline \multicolumn{2}{|c|}{ Model } & $\begin{array}{c}\text { Sum of } \\
\text { Squares }\end{array}$ & $\mathrm{df}$ & $\begin{array}{c}\text { Mean } \\
\text { Square }\end{array}$ & $\mathrm{F}$ & Sig. \\
\hline \multirow{3}{*}{1} & Regression & 21.634 & 2 & 10.817 & 23.793 & $.000^{\mathrm{b}}$ \\
& Residual & 25.914 & 57 & .455 & & \\
& Total & 47.548 & 59 & & & \\
\hline
\end{tabular}

a. Dependent Variable: Behavioural Intention

b. Predictors: (Constant), Subjective Norm, Attitude

The above Table 4 determines whether the predictor variables of the study account for significant variance in the outcome variable (dependent variable). Accordingly, the significant value is less than 0.05 and it demonstrate that there is a significant variance between predictors (attitude and subjective norm) and the dependent variable (behavioural intention). This implies that guests' willingness to spend more on renewable energy is depending on their attitude and subjective norm.

Table 5. Coefficients.

\begin{tabular}{|c|c|c|c|c|c|}
\hline Model & \multicolumn{2}{|c|}{$\begin{array}{c}\text { Unstandardized } \\
\text { Coefficients }\end{array}$} & $\begin{array}{c}\text { Standardize } \\
\mathrm{d} \\
\text { Coefficients }\end{array}$ & $\mathrm{t}$ & Sig. \\
\cline { 2 - 5 } & $\mathrm{B}$ & Std. Error & Beta & & \\
\hline (Constant) & .370 & .505 & & .732 & .467 \\
Attitude & .373 & .150 & .287 & 2.485 & .016 \\
Subjective & .521 & .126 & .477 & 4.140 & .000 \\
Norm & & & & \\
\hline
\end{tabular}

a. Dependent Variable: Behavioural Intention 
The above Table 5 demonstrates the coefficient of predictor variables, attitude and subjective norm. The first hypothesis $\left(\mathrm{H}_{1}\right)$ was to test whether guests' attitude impact on willingness to pay a premium for renewable energy under the significance level of 0.05 . Accordingly, significant value for attitude is 0.016 which is less than 0.05 ( $\mathrm{Sig}=0.016<0.05)$ thus, accepting $\mathrm{H}_{1}$. The second hypothesis $\left(\mathrm{H}_{2}\right)$ was to test whether subjective norm impact on willingness to pay a premium. The significant value for subjective norm is 0.000 which is less than 0.05 ( $\mathrm{Sig}=$ $0.000<0.05$ ) and therefore, accepting $\mathrm{H}_{2}$. This indicates that attitude and subjective norm impacted on behavioural intention or in other words the gusts' willingness to spend more for renewable energy is depending on their attitude towards the environment and social pressure to perform the respective behaviour. According to the above table, unstandardized coefficient has been considered as the data has taken from a common scale and resulted in $\mathrm{B} 1=0.373$ and $\mathrm{B} 2=0.521$. This represents when the attitude increases by one unit, the behavioural intention (willingness to pay a premium) expected to increase by 0.373 units, with no change in subjective norm. Further, without a change in attitude, one unit increase in subjective norm, behavioural intention expected to increase by 0.521 units. Thus, subjective norm has a more impact on behavioural intention comparing to the gusts' attitude.

Therefore, the regression equation can be developed as follows for this study,

Equation (1):

Behavioural Intention (Willingness to pay a premium) $=0.370$ +0.373 (Attitude) +0.521 (Subjective Norm) $+\varepsilon$

\section{CONCLUSIONS}

The main purpose of this study was to investigate how the guests' attitude and subjective norm impact on their willingness to pay a premium for renewable energy use in hotels within the framework of Theory of Reasoned Action (TRA). The current research findings aligning with previous studies in many ways. The correlation analysis suggested that guests' attitude (independent variable) has a positive moderate relationship with their willingness to pay a premium for renewable energy (dependent variable). Further, it was revealed that when the attitude increases by one unit, the behavioural intention (willingness) expected to increase by 0.373 units and the there is a significant impact under the level of 0.05 . When considering about the relationship between subjective norm (independent variable) and the gusts' willingness to pay a premium (dependent variable), there is a positive moderate relationship between two variables and that relationship is stronger comparing to the relationship with attitude. Moreover, the regression analysis suggested that one unit increase in subjective norm, behavioural intention expected to increase by 0.521 , depicting that social pressure has a strong significant impact on gusts' willingness to pay a premium for renewable energy. The overall results are corresponding with the findings of the study conducted by Bang et al. (2000) where the guests who are having a favourable attitude and concern about environment are willing to spend more for the hotels that use renewable energy. The finding further supported the Theory of Reasoned Action developed by Fishbein and Ajzen (1975) suggesting that behavioural intention depend on attitude toward the behaviour, and the subjective norms. Also, it was revealed that there is a significant positive correlation between guests' attitude and subjective norm.
When considering the practical implication, the findings of this study lead to understand the attitude of the guests towards renewable energy practices of the hotels and their intention to pay an extra amount for such initiatives. Thus, using the renewable energy in hotels will become a great tool to increase the guests' confident in green practices while creating a positive attitude towards their decision in paying a premium. Since the social norm too has a significant impact on the guests' intention to pay a premium for renewable energy practices, the government can support to increase the public awareness about energy conservation measures and the government can further implement policies to ensure the environmental standardization in hotels. Moreover, the hoteliers can promote their renewable energy practices through social media to create an awareness among the public which in turn will lead to have a positive social norm leading to pay an extra amount for utilising environmentally sound hotel services. The researchers finally recommend that future research can investigate the factors affecting on hoteliers' intention towards implementing renewable energy practices.

\section{REFERENCES}

1. Ajzen, I., Albarracín, D. Predicting and changing behavior: A reasoned action approach. In. Ajzen, I., Albarracín, D., Hornik, R.: Prediction and change of health behavior: Applying the reasoned action approach. Lawrence Erlbaum Associates Publishers: NJ (2007).

2. Ajzen, I., Fishbein, M.: Understanding attitudes and predicting social behaviour. Prentice-Hall: NJ (1980).

3. Ajzen, I.: The theory of planned behavior. Organizational behavior and human decision processes, 50(2), 179-211 (1991).

4. Bang, H., Ellinger, A.E.: Consumer Concern, Knowledge, Belief, and Attitude toward Renewable Energy: An Application of the Reasoned Action Theory. Journal of Psychology \& Marketing 17(6), 449-468 (2000).

5. Ceylon Electricity Board (CEB), Statistical Digest 2017, Available https://www.ceb.lk/front_img/img_reports/1536209909CE B_Statistical_Digest_2017_-_Web.pdf, last accessed 2018/12/09.

6. Farhar, B. C.: Energy and the environment: the public view. REPP Issue, 3, 1-11 (1996).

7. Fishbein, M., Ajzen, I.: Belief, attitude, intention and behavior: An introduction to theory and research. Reading, MA: Addison - Wesley (1975).

8. Gleason, G., de Alba, R., \& Fish, R.: Will consumers pay for cleaner energy? . Marketing News, 30, 37-39 (1996).

9. Hieu,V., Rasovska, I.: A Proposed Conceptual Model Of Green Practices Impacting On The Tourism Businesses And Their Performances - A Case Of Phu Quoc Island Vietnam. Business Trends, 7(1), 76-87 (2017).

10. International Finance Corporation - World Bank Group, Ensuring Sustainability in Sri Lanka's Growing Hotel Industry. Available at https://www.ifc.org/wps/wcm/connect/30f331004fddd89eb 9d8ff23ff966f85/Mapping+Report++-

+Ensuring+Sustainability+in+Sri+Lanka\%E2\%80\%99s+H otel+Industry.pdf?MOD=AJPERES, last accessed 2018/12/05.

11. Kamieniecki, S., George, A., Gonzalez, Vos, R.: Flashpoints in Environmental Policymaking. State University of New York Press: Albany (1997). 
12. Kostakis, I., Sardianou, E.: Which factors affect the willingness of tourists to pay for renewable energy? . Renewable Energy, 38, 169-172 (2011).

13. Manaktola, K., Jauhari,V.: Exploring consumer attitude and behaviour towards green practices in the lodging industry in India, International Journal of Contemporary Hospitality Management, 19(5), 364-377 (2007).

14. Manzo, G. Travel \& Tourism, Economic Impact 2018, Sri Lanka. Available at https://www.wttc.org//media/files/reports/economic-impact-research/countries2018/srilanka2018.pdf, last accessed 2018/12/07.

15. Miller, Katherine: Communication Theories: Perspectives, Processes, and Contexts. McGraw-Hill Education: New York (2005).

16. National Water Supply and Drainage Board, Annual Report 2015 , Available http://www.waterboard.lk/web/index.php?option=com_co ntent $\&$ view $=$ article $\&$ id $=56 \&$ Itemid= $216 \&$ lang=en, last accessed 2018/12/09.

17. Ntanos, S., Kyriakopoulos, G., Chalikias, M., Arabatzis, G., Skordoulis, M.: Public Perceptions and Willingness to Pay for Renewable Energy: A Case Study from Greece. Sustainability, 10, 687 (2018).

18. Pushpakumara, C., Nanayakkara, J., Withanaarachchi, A.: The Progress of Sri Lanka's Renewable Energy Sector Developments in Mitigating the GHG Emission. Energy and Environmental Engineering 2(5), 113-119 (2014).

19. Ribeiro, F., Ferreira, P., Araújo, M., Braga, A.C.: Public opinion on renewable energy technologies in Portugal. Energy, 69, 39-50 (2014).

20. Sri Lanka Tourism Development Authority, Annual statistical report 2017, Available at http://www.sltda.lk/sites/default/files/annual-staticalreport-2017.pdf, last accessed 2018/12/09.

21. Wang, J., Ritchie, B. W.: A theoretical model for strategic crisis planning: factors influencing crisis planning in the hotel industry. International Journal of Tourism Policy, 3(4), 297-317 (2010).

22. Wang, J., Ritchie, B. W.: Understanding accommodation managers' crisis planning intention: An application of the theory of planned behaviour. Tourism Management, 33(5), 1057-1067 (2012). 